\title{
ACCURACY OF SPRINGATE, ZMIJEWSKY AND GROVER AS LOGISTIC MODELS IN FINDING FINANCIAL DIFFICULTY OF FINANCING COMPANIES
}

\author{
Munawarah ${ }^{1}$, Keumala Hayati ${ }^{1}$ \\ aUniversitas Prima Indonesia Medan, Indonesia \\ Email: munawarah1710@yahoo.com \\ Email: keumalahayatihakim@gmail.com
}

\begin{tabular}{|c|c|}
\hline INFO ARTIKEL & ABSTRAK/ABSTRACK \\
\hline $\begin{array}{l}\text { Histori Artikel: } \\
\text { Tgl. Masuk : } 02 \text { Februari } 2019 \\
\text { Tgl. Diterima : 01 Maret } 2019 \\
\text { Tersedia Online 29 Maret } \\
2019 \\
\text { Keywords: } \\
\text { Springate Model, Zmijewski } \\
\text { Model, Grover Model, } \\
\text { Financial Distress }\end{array}$ & $\begin{array}{l}\text { This study aims to determine both the Springate model, } \\
\text { Grover and Zmijewski able to predict the condition of } \\
\text { financial distress in finance companies listed on the } \\
\text { Indonesia Stock Exchange. And of the three models can } \\
\text { be known which model is the most accurate in predicting } \\
\text { financial distress. The population in this study are } \\
\text { companies in the financing sector listed on the Indonesia } \\
\text { Stock Exchange in the period } 2013 \text { to } 2017 \text { as many as } 17 \\
\text { companies. By using purposive sampling technique, a total } \\
\text { sample of } 85 \text { financing companies was obtained. The data } \\
\text { used are secondary data sourced from the company's } \\
\text { annual financial reports. The analysis model used is } \\
\text { logistic regression. Simultaneously, all predictive models } \\
\text { for Springate, Zmijewski, and Grover affect the probability } \\
\text { of financial distress. While partially only Zmijewski can } \\
\text { influence the prediction of financial distress conditions in } \\
\text { Financing sub-sector companies listed on the Indonesia } \\
\text { Stock Exchange. Nagelkerqe Square value shows } 0.606 \\
\text { meaning that only } 60.6 \% \text { variation of the accuracy of these } \\
\text { three models in predicting financial distress conditions of } \\
\text { finance companies. While the remaining } 39.4 \% \text { can be } \\
\text { explained by other models not examined in this study }\end{array}$ \\
\hline
\end{tabular}

\section{PENDAHULUAN}

Perusahaan pembiayaan pada awalnya merupkan perusahaan yang hanya bergerak dalam kegiatan sewa guna usaha. Namun tidak dapat dipungkiri kehadiran perusahaan pembiayaan di Indonesia dua puluh tahun terakhir ini mengalami perkembangan yang pesat. Sebagai perusahaan yang meramaikan industri keuangan dan telah dikenal masyarakat Indonesia, keberadaan perusahaan ini mampu mendorong pertumbuhan ekonomi di Indonesia melalui kegiatan pembiayaan konsumen dalam pengadaan berbagai macam barang seperti elektronik, kendaraan roda dua, roda empat, dan lainnya. Tak dapat dipungkiri, industri pembiayaan ini juga mendorong tumbuhnya industri otomotif dan industri perbankan.

Semakin berkembang pesatnya industri ini diperlukan suatu pengawasan dan menetapkan regulasi terkait dengan aktivitas pembiayaan yang dilakukan. Tingkat kesehatan perusahaan pembiayaan perlu diawasi oleh OJK mengingat selama ini persepsi yang ada bahwa industri ini berkaitan dengan "shadow banking" karena dianggap masih belum mandiri dalam hal kecukupan modalnya yang sebagaian besar berasal 
dari dana yang dikucurkan perusahaan perbankan.

Perusahaan pembiayaan merupakan bisnis yang berbeda jika dibandingkan dengan perusahaan non jasa keuangan lainnya. Perusahaan jenis ini memiliki rasio leverage yang cukup tinggi karena penggunaan utang sebagai sumber modal yang banyak berasal dari perbankan, dan dibandingkan dengan modal sendiri. Hal ini menyebabkan struktur aktiva dan kewajiban perusahaan menjadi tidak seimbang. Maka tidak dapat dipungkiri perusahaan pembiayaan ini rentan terhadap resiko, terutama resiko likuiditas, akibat komposisi aset dan liabilitas yang tidak berimbang. Sebagian besar sumber dana yang diperoleh dari perbankan umumnya bersifat jangka pendek, sementara pembiayaan yang dilempar ke pasar umumnya berjangka menengah. Jika tidak diatasi, akan berdampak pada kegagalan perusahaan pembiayaan mengingat perusahaan ini dipandang sebagai lembaga kepercayaan.

Dalam hal pemberian pinjaman dengan jangka waktu satu tahun atau lebih, diperlukan seorang analis untuk menganalisa serta memberikan opini atas resiko pembiayaan yang muncul. Setiap ketidakpastian yang muncul terkait dengan pengelolaan perusahaan pembiayaan, akan berpotensi memberi dampak terhadap keuangan perusahaan. Dalam menilai resiko perusahaan pembiayaan Pasal 4 ayat (2) Peratutan Otoritas Jasa Keuangan Nomor 10/POJK.05/2014 menyebutkan salah satu resiko yang kerap terjadi adalah resiko likuiditas. Resiko ini terjadi karena adanya potensi kegagalan dalam mengelola aset dan liabilitas yang berdampak pada kurangnya dana dalam memenuhi kewajiban perusahaan. Selain itu resiko pembiayaan juga menjadi faktor penentu kesehatan suatu perusahaan pembiayaan, yang terjadi akibat kegagalan debitur dalam melunasi kembali kewajiban angusran atas pembiayaan yang sudah diterima ditandai dengan membengkaknya rasio pembiayaan bermasalah (Non Performing Financing (NPF). Hal ini menjadi resiko terbesar yang dapat menyebabkan kesulitan keuangan bagi perusahaan pembiayaan, karena sebagian besar aset perusahaan merupakan piutang pembiayaan dari debitur.

Pada akhirnya kondisi seperti ini membuat perusahaan pembiayaan rentan menghadapi kesulitan keuangan atau disebut financial distress akibat perusahaan yang tidak mampu mengelola dan menjaga kestabilan kinerja keuangan perusahaan. Kegagalan perusahaan dalam mengelola kualitas aktiva produktif dapat menyebabkan turunnya tingkat kolektabilitas tagihan pembiayaan yang mengakibatkan hilangnya potensi perusahaan mendapatkan pendapatan operasional. Selain itu perusahaan akan berpotensi mengalami kerugian operasional dan kerugian bersih tahun berjalan. Kerugian yang terjadi akan menyebabkan defisiensi modal karena penurunan saldo laba. Laba banyak tergerus untuk membayar pokok dan bunga pinjaman, dan akibatnya total ekuitas sebagai sumber modal juga akan mengalami penurunan secera keseluruhan. Efeknya total kewajiban akan jauh melebihi total aset pada perusahaan pembiayaan. Pada akhirnya kondisi dapat menyebakan perusahaan pembiayaan mengalami kesulitan keuangan dan jika tidak mampu segera mengatasinya, akan berdampak pada kepailitan.

Model prediksi kesulitan keuangan menjadi hal penting yang harus dipertimbangkan sebab banyaknya pihak terkait dalam perusahaan pembiayaan. Sebagai perusahaan yang hanya 
memberikan jasa pembiayaan atau kredit, menyebabkan perusahaan banyak bergantung kepada pihak lain seperti kreditur, perbankan, dealer, vendor, merchant, dan lainnya. Tingkat kesulitan keuangan menjadi pusat perhatian penting bagi mereka, karena akan menggambarkan kondisi perusahaan pembiayaan baik kemungkinan gagal bayar maupun kemungkinan dari kerugian finansial yang diderita akibat resiko gagal bayar debitur. Ada banyak model prediksi yang telah diteliti oleh peneliti sebelumnya seperti Model Springate, model Zmijewski, dan model Grover. Model-model ini merupakan model modifikasi dari model Altman dengan menggunakan teknik Multiple Diskriminan Analysis (MDA). Pengukuran model ini menggunakan berbagai rasio keuangan yang dapat memprediksi kesulitan keuangan

Hasil penelitian dari masing-masing model ini masih memiliki banyak perbedaan. Prihantini (2013) menyatakan bahwa pada hasil penelitiannya model Grover merupakan model prediksi yang paling sesuai diterapkan pada perusahaan Sektor makanan dan minuman di Indonesia. Sejalan dengan model penelitian Syahfitriani (2017) juga menyatakan model Grover yang paling tepat untuk memprediksi kondisi Financial distress pada perusahaan pertambangan. Sedangkan menurut Adriana dan Nasir (2012) menyatakan berdasarkan hasil penelitian mereka justru model Grover yang mempunyai tingkat akurasi paling tinggi sebesar $92,5 \%$ untuk memprediksi kondisi financial distress atau potensi kebangkrutan perusahaan. Berdasarkan uraian tersebut maka perlu dirumuskan kembali diantara ketiga model Springate, Zmijewski, dan Grover dapat memprediksi kondisi kesulitan keuangan (financial distress) pada perusahaan Pembiayaan serta model manakah yang paling akurat dalam memprediksi kondisi kesulitan keuangan.

\section{KERANGKA TEORITIS DAN PENGEMBANGAN HIPOTESIS}

\section{Kinerja Perusahaan}

Menurut Courtland (2003:10) kinerja perusahaan dapat diartikan sebagai peningkatan yang dicapai oleh individu atau kelompok dalam memimpin suatu perusahaan (organisasi) dan mencapai tujuan perusahaan tersebut dengan efektif dan efisien.

Syahyunan (2013) menjelaskan pengertian berbagai jenis rasio keuangan sebagai pengukuran kinerja perusahaan sebagai berikut. Rasio likuiditas merupakan rasio yang digunakan untuk mengetahui kemampuan perusahaan dalam memenuhi kewajiban jangka pendeknya secara tepat waktu. rasio likuiditas merupakan rasio yang menunjukkan hubungan antara kas dan aset lancar perusahaan lainnya dengan kewajiban lancarnya. Rasio leverage atau solvabilitas digunakan untuk mengetahui kemampuan perusahaan dalam melunasi utang-utangnya atau dengan kata lain rasio ini digunakan untuk mengetahui bagaimana perusahaan mendanai kegiatan usahanya apakah lebih banyak menggunakan utang atau ekuitas. Rasio aktivitas digunakan untuk mengetahui seberapa efektif manajemen perusahaan menggunakan aktiva yang dimilikinya dalam melaksanakan kegiatan perusahaan. Dan rasio profitabilitas digunakan untuk mengetahui kemampuan perusahaan dalam menghasilkan laba atau seberapa efektif pengelolaan perusahaan oleh manajemen.

\section{Kesulitan Keuangan}


Kesulitan Keuangan (Financial Distress) menurut Wijoyo (2016) dimulai ketika suatu perusahaan tidak mampu memenuhi jadwal pembayaran atau ketika proyeksi arus kas mengindikasikan bahwa perusahaan tersebut akan segera tidak dapat memenuhi kewajibannya.

\section{Teori Kesulitan Keuangan}

Elrich (2003:40) dalam Swantari (2012:6) menyebutkan bahwa penyebab kesulitan keuangan digolongkan menjadi dua faktor, yaitu:

1. Faktor Internal, antara lain :

a. Kredit yang diberikan kepada pelanggan terlalu besar.

b. Lemahnya kualifikasi sumber daya manusia dalam hal skill, pengalaman, sifat cepat tanggap, dan inisiatif dapat menghambat bahkan tidak tercapainya tujuan perusahaan.

c. Kekurangan modal kerja.

d. Penyalahgunaan wewenang dan kecurangan.

e. Keadaan perekonomian yang buruk.

2. Faktor Eksternal, antara lain :

a. Persaingan bisnis yang ketat

b. Berkurangnya permintaan terhadap produk atau jasa yang dihasilkan

c. Turunnya harga jual secara terus menerus

d. Kecelakaan atau bencana alam yang menimpa perusahaan

3. Faktor Internal, antara lain :

a. Kredit yang diberikan kepada pelanggan terlalu besar.

b. Lemahnya kualifikasi sumber daya manusia dalam hal skill, pengalaman, sifat cepat tanggap, dan inisiatif dapat menghambat bahkan tidak tercapainya tujuan perusahaan.

c. Kekurangan modal kerja.

d. Penyalahgunaan wewenang dan kecurangan.

e. Keadaan perekonomian yang buruk.

4. Faktor Eksternal, antara lain :

a. Persaingan bisnis yang ketat

b. Berkurangnya permintaan terhadap produk atau jasa yang dihasilkan c. Turunnya harga jual secara terus menerus

d. Kecelakaan atau bencana alam yang menimpa perusahaan

\section{Model Prediksi Kebangkrutan}

\section{Model Springate}

Merupakan hasil penelitian yang dilakukan oleh Gordon L.Springate di tahun 1978 dengan sampel perusahaan di Kanada. Beliau mengukur kesulitan keuangan berdasarkan 4 rasio keuangan perusahaan. Rumus model ini adalah sebagai berikut :

S-Score $=1,03 \mathrm{~A}+3,07 \mathrm{~B}+0,66 \mathrm{C}+0,4$

Keterangan :
A $=$ Working Capital to Total Asset
$\mathrm{B}=E B I T$ to Total Asset
$\mathrm{C}=\mathrm{EBT}$ to Current Liabilities
D = Sales to Total Asset

Nilai cut-off yang berlaku untuk model ini adalah 0,862. Jika Nilai $S<0,862$ menunjukkan bahwa perusahaan tersebut diprediksi akan mengalami kebangkrutan. Sebaliknya jika nilai S-Score $>0,862$ maka perusahaan dikategorikan sehat.

\section{Model Zmijewski}

Zmijewski melakukan penelitian tahun 1983 dengan rentang waktu riset selama 20 tahun. Zmijewski menyatakan bahwa rasio profitabilitas, likuiditas dan leverage sebagai variabel terpenting dalam memprediksi kondisi financial distress perusahaan. Sampel yang digunakan sebanyak 148 perusahaan dengan kategori 75 perusahaan mengalami financial distress, dan 73 perusahaan lainnya dalam kondisi sehat dari tahun 1972-1978. Hasil penelitian menghasilkan rumus sebagai berikut : $X$-Score $=-4,3-4,5 X_{1}+5,72 X_{2}-0,004 X_{3}$

Keterangan :

$\mathrm{X} 1=$ Return on Asset (ROA) 
$\mathrm{X}_{2}=$ Debt to Asset Ratio (DAR)

$\mathrm{X}_{3}=$ Current Ratio

Jika nilai X-Score $>0$ maka perusahaan yang diprediksi mengalami kesulitan keuangan (financial distress). Jika nilai $\mathrm{X}$-Score $<0$ maka perusahaan diprediksi tidak berpotensi untuk mengalami kesulitan keuangan

\section{Model Grover}

Jeffrey S.Grover telah melakukan penelitian pada tahun 2001 dan sampel yang digunakan sama seperti pada model Altman, sebanyak 70 perusahaan dengan klasifikasi ada 35 perusahaan yang berpotensi mengalami financial distress, dan sisanya tidak mengalami kesulitan keungan. Grover menambahkan 13 rasio keuangan baru untuk melihat kondisi perusahaan pada tahun 1982-1996. Hasil penelitian tersebut, diperoleh rumus model Grover sebagai berikut :

G-Score $=1,65$ X1+3,404 X2-

$$
0,016 \times 3+0,057
$$

Keterangan :

X1 = Working Capital to Total Asset

$\mathrm{X} 2=$ Earning Before Interest and Tax to Total Asset

$\mathrm{X} 3=$ Net Income Tax to Total Asset

Perusahaan dikategorikan bangkrut atau mengalami financial distress jika nilai G-Score $\leq-0,02$. Sebaliknya perusahaan dikategorikan sehat dan tidak mengalami financial distress jika nilai G-Score $\geq 0,01$.

\section{Kerangka Konseptual dan Hipotesis}

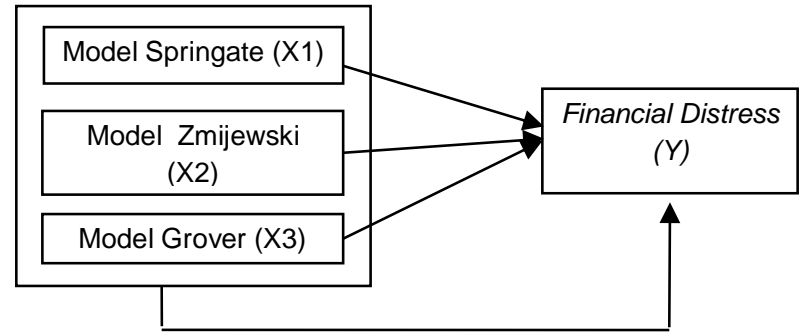

Gambar 1. Kerangka Konseptual

Berdasarkan kerangka konseptual dan uraian model prediksi kebangkrutan yang digunakan maka dapat dikembangkan Hipotesis penelitian dari penggunaan Model Springate melalui SScore, Model Zmijewski melalui X-score dan Model Grover melalui G-score dapat memprediksi probabilitas terjadinya kondisi kesulitan keuangan dan mana yang paling akurat dalam memprediksi kesulitan keuangan pada perusahaan pembiayaan yang terdaftar di Bursa Efek Indonesia Tahun 2013-2017.

\section{METODOLOGI PENELITIAN}

Populasi dalam penelitian ini adalah perusahaan-perusahaan yang tergabung sub sektor lembaga pembiayaan yang terdaftar di Bursa Efek Indonesia tahun 2013-2017 sebanyak 17 perusahaan pembiayaan. Pemilihan sampel digunakan teknik purposive sampling dengan kriteria : (1). Perusahaan Pembiayaan yang terdaftar secara berturut-turut di Bursa Efek mulai tahun 2013-2017. ( 2). Perusahaan Pembiayaan yang menyajikan laporan keuangan tahunan yang sudah diaudit berturut-turut tahun 2013-2017. Total sampel diperoleh 15 perusahaan dikali 5 tahun pengamatan menjadi 75 perusahaan.

Jenis data yang digunakan adalah data sekunder bersumber dari laporan keuangan tahunan perusahaan pembiayaan tahun 2013 sampai 2017. Pendekatan penelitian menggunakan deskriptif kuantitatif.

\section{Identifikasi dan Definisi Operasional Variabel Penelitian}

1. Variabel independen

Variabel independen dalam penelitian ini adalah model prediksi financial distress yang terdiri dari model Springate, Zmijewski, dan 
Grover dengan penjelasan masing-masing rasio sebagai berikut :

a. Working Capital to Total Asset merupakan bagian dari rasio perputaran modal kerja. Rasio ini diukur untuk mengetahui seberapa efektif manajemen dalam menggunakan aktiva yang dimiliki sebagai modal kerja dalam kegiatan perusahaan. Rumus :

Working Capital turnover $=\frac{\text { Working Capital }}{\text { Total Asset }}$

b. EBIT to Total Asset sering disebut juga rasio rentabilitas ekonomi. Rasio ini diukur untuk mengetahui seberapa efektif pengelolaan aktiva yang dapat menghasilkan laba perusahaan. Rumus :

$$
E B T A=\frac{E B I T}{\text { Total Asset }}
$$

c. EBT to Current LiabilitieS merupakan bagian dari rasio likuiditas yang mengukur kemampuan perusahaan dalam menyelesaikan kewajiban jangka pendeknya tepat waktu atau sebelum jatuh tempo dari laba yang dihasilkan. Rumus :

$$
E B T C L=\frac{E B I T}{\text { Current Liabilities }}
$$

d. Sales to total asset merupakan bagian rasio yang mengukur seberapa efektif manajemen dalam menggunakan aktiva yang dimiliki dalam kegiatan perusahaan. Rumus :

$$
\text { Total Asset turnover }=\frac{\text { Sales }}{\text { Total Asset }}
$$

e. Return on Asset merupakan bagian dari rasio Profitabilitas diukur melalui perbandingan antara laba bersih setelah pajak dibagi dengan total aktiva perusahaan. Rumus :

$$
R O A=\frac{\text { Earning } \text { After } \operatorname{Tax}}{\text { Total } \text { Asset }}
$$

f. Debt to Asset Ratio merupakan bagian dari rasio solvabilitas atau leverage yang mengukur kemampuan perusahaan dalam melunasi seluruh utang-utangnya. Diukur dengan membandingkan total utang dengan total aktiva perusahaan. Rumus :

$$
D A R=\frac{\text { Total } D e b t}{\text { Total } A s s e t}
$$

g. Current Ratio merupakan bagian rasio Likuiditas yang mengukur kemampuan perusahaan dalam menyelesaikan kewajiban jangka pendeknya tepat waktu atau sebelum jatuh tempo. Rumus :

Current Ratio $=\frac{\text { Current Asset }}{\text { Current liabilities }}$

h. Variabel dependen dalam penelitian ini adalah Financial distress yang merupakan tahap penurunan kondisi keuangan perusahaan sebelum terjadinya kebangkrutan. Variabel dependen merupakan variabel dikotomi (dummy) karena memiliki kategori berdasarkan kondisi yang terjadi. Nilai " 0 " diberikan jika perusahaan mengalami financial distress dengan indikasi mengalami kerugian lebih dari satu tahun dan tidak melakukan pembayaran dividen. Sedangkan nilai "1" diberikan jika perusahaan tidak mengalami financial distress dilihat dari perolehan laba dan

\begin{tabular}{|c|c|c|c|c|c|}
\hline & $N$ & Min & Max & Mean & $\begin{array}{l}\text { Std. } \\
\text { Deviation }\end{array}$ \\
\hline SPRINGATE & 75 & -.756 & 2.1010 & .71997 & .43245 \\
\hline ZMIJEWSKI & 75 & -5.887 & 84.4990 & 15.3452 & 14.6743 \\
\hline GROVER & 75 & -1.064 & 2.0807 & .9063 & .54833 \\
\hline $\begin{array}{ll}\text { Valid } & N \\
\text { (listwise) } & \end{array}$ & 75 & & & & \\
\hline
\end{tabular}
pembayaran dividennya.

\section{HASIL DAN PEMBAHASAN}

\section{Statistik Deskriptif}

Tabel 1. Descriptive Statistics

Sumber : Data diolah peneliti (2018)

Tabel di atas menunjukkan nilai maksimum dari model Springate adalah sebesar 2,1010 dan nilai minimum sebesar -0,756. Model Zmijewski menunjukkan nilai maksimum sebesar $.84,499$ dan nilai minimum sebesar $-5,887$. Dan pada model Grover menunjukkan nilai maksimum sebesar 2,0807 dan nilai 
minimum sebesar $-1,064$.

Uji Kelayakan Model (Goodness of Fit Test)

Tabel 2 Hosmer and Lemeshow Test

\begin{tabular}{|l|r|r|l|}
\hline Step & Chi-square & df & \multicolumn{1}{l|}{ Sig. } \\
\hline 1 & 6.871 & 7 & .442 \\
\hline
\end{tabular}

Sumber : Data diolah peneliti (2018)

Tabel diatas menunjukkan nilai Chi square sebesar 6,871 dan nilai degree of freedom (df) 7 dengan nilai signifikansi $0,442>0,05$. Artinya model regresi logistik dianggap fit dan sesuai sehingga dapat digunakan untuk uji selanjutnya.

Uji Keseluruhan Model (Overall Model Fit)

Tabel 3. Overal Model Fit beginning Block (Block =0)

\begin{tabular}{|c|c|c|}
\hline \multirow[b]{2}{*}{ Iteration } & \multirow{2}{*}{$\begin{array}{l}-2 \text { Log } \\
\text { likelihood }\end{array}$} & Coefficients \\
\hline & & Constant \\
\hline Step 0 & 102.353 & .293 \\
\hline & 102.353 & .295 \\
\hline & 102.353 & .295 \\
\hline
\end{tabular}

Sumber : Data diolah peneliti (2018)
Tabel 4. Hasil Uji Overall Model Fit Beginning Block (Block =1)

\begin{tabular}{|c|c|c|c|c|c|}
\hline \multirow[b]{2}{*}{ Iteration } & \multirow[b]{2}{*}{$\begin{array}{l}-2 \text { Log } \\
\text { likelihood }\end{array}$} & \multicolumn{4}{|c|}{ Coefficients } \\
\hline & & Constant & $\begin{array}{c}\text { SPRING } \\
\text { ATE }\end{array}$ & $\begin{array}{c}\text { GROVE } \\
\text { R }\end{array}$ & $\begin{array}{l}\text { ZMIJE } \\
\text { WSKI }\end{array}$ \\
\hline Step 11 & 61.373 & 1.475 & 2.162 & -1.290 & -.108 \\
\hline 2 & 57.639 & 2.106 & 3.702 & -2.378 & -.152 \\
\hline 3 & 57.386 & 2.334 & 4.470 & -2.957 & -.168 \\
\hline 4 & 57.384 & 2.358 & 4.570 & -3.035 & -.169 \\
\hline 5 & 57.384 & 2.358 & 4.572 & -3.036 & -.169 \\
\hline 6 & 57.384 & 2.358 & 4.572 & -3.036 & -.169 \\
\hline
\end{tabular}

Sumber : Data diolah peneliti (2018)

Nilai -2 LL pada blok pertama sebesar 102,353. Sedangkan nilai 2LL pada blok kedua sebesar 57,384 . Hal ini dapat menjelaskan bahwa ketika model hanya dengan konstanta saja tanpa adanya variabel bebas menunjukkan penurunan dari 102,353 menjadi 57,384 .. Penurunan model keseluruhan (Overall model fit) pada 2 Log likelihood block number $=0$ ke -2 Log likelihood block number $=1$ sebesar 44,969. Dapat disimpulkan penurunan nilai likelihood menunjukkan model penelitian dinyatakan fit atau layak. Artinya model yang telah dihipotesakan fit dengan data.

\section{Koefisien Determinasi}

Tabel 5. Nagelkerke R Square

\begin{tabular}{|l|r|r|r|}
\hline Step & $\begin{array}{c}-2 \text { Log } \\
\text { likelihood }\end{array}$ & $\begin{array}{c}\text { Cox \& Snell R } \\
\text { Square }\end{array}$ & $\begin{array}{l}\text { Nagelkerke R } \\
\text { Square }\end{array}$ \\
\hline 1 & $57.384^{\mathrm{a}}$ & .451 & .606 \\
\hline
\end{tabular}

Sumber : Data diolah peneliti (2018)

Berdasarkan tabel tersebut menunjukkan bahwa nilai uji -2 Log 
Likelihood sebesar 57,384. Nilai Nagelkerke $R$ Square 0,606, dapat dikatakan variabilitas variabel independen untuk menjelaskan variabel dependennya adalah sebesar $60,6 \%$. Sisanya sebesar $39,4 \%$ dapat dijelaskan oleh faktor-faktor lain yang tidak diikutsertakan dalam model penelitian.

\section{Uji Simultan ( $F$ test)}

Tabel 6. Omnibus Test Of Model Coefficient

Sumber : Data diolah peneliti (2018)

Nilai Chi Square sebesar 44,969 dengan degree of freedom adalah 3 , dan tingkat signifikansi sebesar $0,000<0,05$. Dapat disimpulkan bahwa model Springate, Zmijewski, dan Grover secara simultan berpengaruh signifikan terhadap kondisi kesulitan keuangan (Financial Distress) pada perusahaan pembiayaan di Bursa Efek Indonesia.

\section{Uji Individual (Uji Parsial t-Test)}

Tabel 7. Pengujian Koefisien Regresi

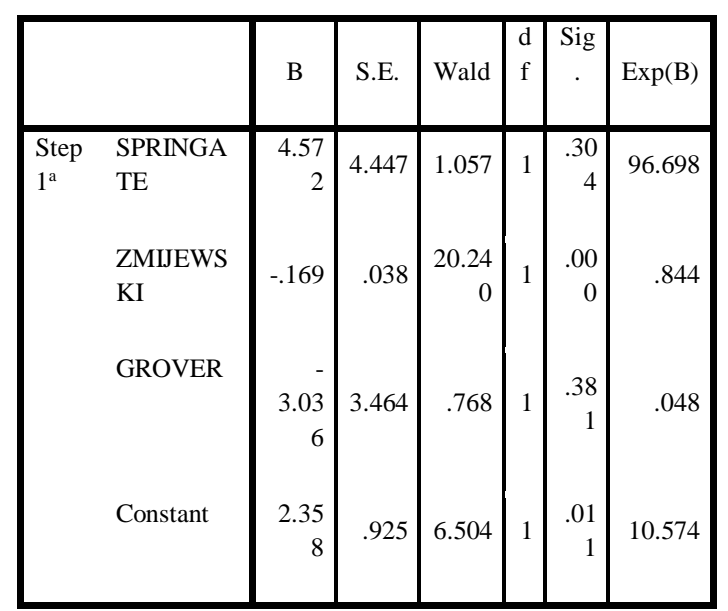

Sumber : Data diolah peneliti (2018)

Berdasarkan hasil uji koefisien regresi, dapat diperoleh persamaan regresi logistik menjadi sbb :

$$
\begin{aligned}
& \operatorname{Ln} \frac{p}{1-p}=2,358+4,572 \text { Springate - } \\
& \text { 0,169 Zmijewski - 3,036 } \\
& \text { Grover }
\end{aligned}
$$

Hasil persamaan diatas dapat diinterpretasikan bahwa nilai konstanta positif sebesar 2,358. Artinya jika semua variabel diabaikan maka peluang terjadinya debitur macet justru akan meningkat. Nilai signifikansi konstanta 0,011 yang berarti signifikan terhadap probabilitas financial distress.

Koefisien Springate memiliki tanda positif dengan nilai sebesar 4,572 . Artinya setiap kenaikan model Springate sebesar satu satuan akan menaikkan peluang terjadinya financial distress. Dengan nilai signifikansi 0,304 menunjukkan pengaruh variabel ini tidak signifikan terhadap probabilitas terjadinya financial distress.

Koefisien Zmijewski memiliki tanda negatif sebesar $-0,169$. Artinya setiap kenaikan model Zmijewski sebesar satu satuan akan menurunkan peluang terjadinya financial distress. Dengan nilai

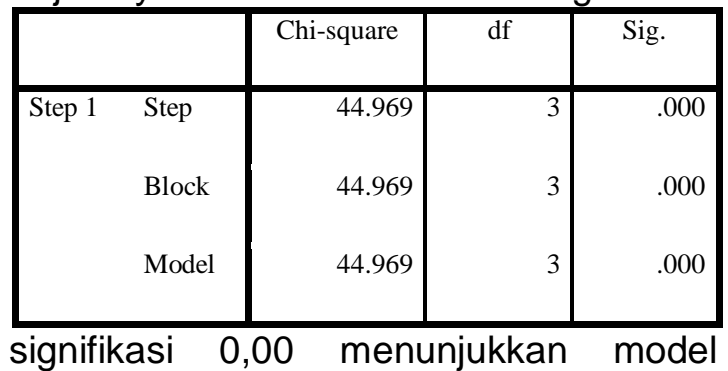

Zmijewski ini berpengaruh signifikan terhadap probabilitas terjadinya financial distress.

Koefisien Grover memiliki tanda negatif sebesar -3,036. Artinya setiap kenaikan model ini sebesar satu satuan akan menurunkan peluang terjadinya financial distress Dengan nilai signifikasi 0,381 menunjukkan pengaruh variabel ini tidak signifikan terhadap probabilitas terjadinya financial distress. 
Berdasarkan hasil uji parsial diperoleh hanya model Zmijewski memiliki pengaruh positif dan signifikan terhadap probabilitas financial distress pada perusahaan pembiayaan. Hasil ini mendukung hipotesa yang menyatakan Model Zmijewski berpengaruh signifikan terhadap probabilitas terjadinya financial distress. Hal ini dapat disebabkan karena pada model ini, rasio keuangan yang diukur tidak hanya terlihat dari rasio laba saja. Namun juga berasal dari komponen rasio leverage (solvabilitas) dan rasio likuiditas. Hasil ini sesuai dengan fungsi utama manajemen keuangan yaitu perusahaan yang mampu bertahan adalah perusahaan yang mampu menjaga keseimbangan komposisi keuangan yang ditandai dari 4 rasio keuangan utama yaitu rasio profitabilitas, solvabilitas, likuiditas, dan aktivitas. Tiga diantara rasio tersebut merupakan rasio utama dalam melihat kondisi keuangan perusahaan. Oleh karena itu manajer harus berhati-hati dalam menafsirkan dan menganalisis rasio keuangan tersebut. Tidak hanya manajer, banyak pihak yang membutuhkannya seperti investor, kreditur, dan pihak lainnya. Pada perusahaan pembiayaan, seringkali yang menjadi masalah utama adalah tingkat likuiditasnya, karena aset lancar yang dimilikinya hampir $80 \%$ ada pada piutang debitur. Selain itu sumber pendanaan yang diperoleh perusahaan pembiayaan umumnya berasal dari bank yang umumnya berjangka waktu pendek, sementara pembiayaan ini sifatnya berjangka menengah. Dari sisi solvabilitas, perusahaan pembiayaan juga memiliki rasio gearing sendiri (komposisi antara utang dan aktiva) yang sudah diatur sedemikian rupa justru menyebabkan struktur aktiva dan kewajiban perusahaan menjadi tidak seimbang. Dari rasio ini jelas, manajer perusahaan akan lebih mudah untuk mengetahui terindikasinya perusahaan mengalami financial distress.
Sementara pada model lainnya seperti Springate dan Grover memiliki nilai signifikansi diatas 0,05 yaitu sebesar 0,381 dan 0,304. Berdasarkannilai tersebut diperoleh hasil bahwa kedua model tersebut tidak memiliki pengaruh signifikan terhadap probabilitas terjadinya financial distress pada perusahaan pembiayaan. Dapat dilihat rasio yang digunakan hanya fokus pada rasio profitabilitas. Hal ini tidak dapat menggambarkan kondisi keuangan perusahaan pembiayaan secara menyeluruh jika hanya terfokus pada perolehan laba. Perolehan laba tidak serta merta mampu memberikan gambaran kemungkinan suatu perusahaan mengalami kesulitan keuangan, karena pada dasarnya setiap pengguna laporan keuangan selalu menganggap bahwa perusahaan yang memperoleh laba berarti tidak mengalami kesulitan keuangan.

\section{Klasifikasi Data Penelitian}

Tabel 8. Klasifikasi Model Analisis

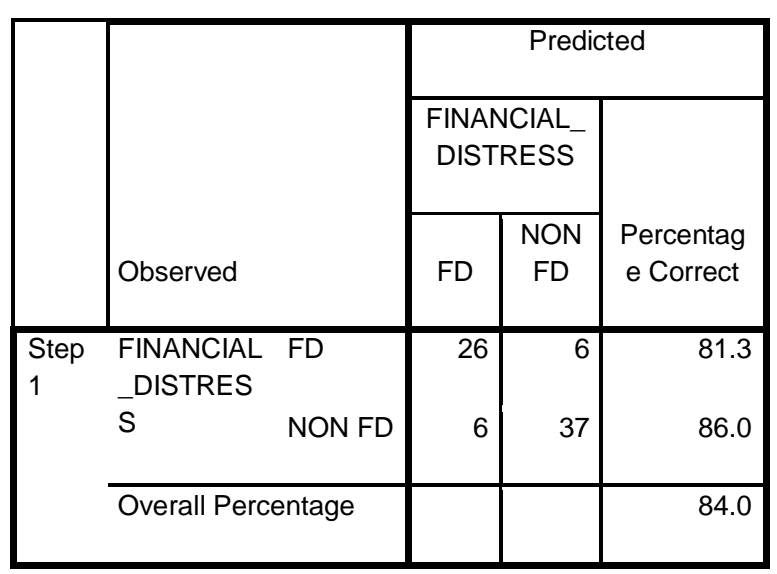

Sumber : Data diolah peneliti (2018)

Pada kolom prediksi klasifikasi perusahaan pembiayaan yang mengalami financial distress sebanyak 32 sedangkan pada nilai observasi yang sesungguhnya diperoleh hanya 26 perusahaan. Ini berarti 
ketepatan model prediksi hanya mampu menyumbang angka 81,3\%. Sementara pada kolom prediksi perusahaan yang tidak mengalami financial distress ada sebanyak 43 sedangkan pada pengamatan yang sebenarnya diperoleh 37 perusahaan. Maka persentase ketepatan model prediksi sebesar $86 \%$. Secara keseluruhan dapat disimpulkan bahwa ketepatan model prediksi sebesar $84 \%$.

\section{KESIMPULAN}

Hasil pengujian dengan menggunakan teknik analisis regresi logistik diperoleh bahwa secara simultan model Springate, Zmijewski dan Grover berpengaruh signifikan terhadap probablitas terjadinya kondisi financial distress pada perusahaan pembiayaan yang terdaftar di Bursa Efek Indonesia tahun 2013-2017. Secara parsial hanya model Zmijewski yang memiliki pengaruh positif dan signifikan terhadap probabilitas financial distress perusahaan dengan nilai $\alpha=5 \%$. Sedangkan model lainnya tidak berpengaruh signifikan terhadap probabilitas terjadinya financial distress pada perusahaan pembiayaan yang terdaftar di Bursa Efek Indonesia tahun 2013-2017.

Nilai Nagelkerke $R$ Square sebesar 0,606 , dikatakan variabilitas variabel independen untuk menjelaskan variabel dependennya adalah sebesar 60,6 \%. Sisanya sebesar $39,4 \%$ dapat dijelaskan oleh faktor-faktor lain yang tidak diikutsertakan dalam model penelitian. Peluang klasifikasi perusahaan yang tidak mengalami kesulitan keuangan (financial distress) sebanyak 43, sedangkan pengamatan sesungguhnya hanya 37 perusahaan. Klasifikasi debitur yang mengalami financial distress ada 32 , dan pada pengamatan sesungguhnya ada 26 perusahaan. Maka peluang persentase keakuratan secara keseluruhan sebesar $84 \%$.

\section{IMPLIKASI DAN KETERBATASAN}

Penelitian mengenai financial distress menjadi topik yang menarik untuk diteliti agar menjadi sistem peringatan tersendiri bagi perusahaan jika perusahaan berada dalam fase yang kurang baik, dan segera mencari penyelesaian sesegera mungkin. Dengan menggunakan model prediksi kebangkrutan yang banyak, maka perusahaan dapat menentukan model mana yang paling tepat dalam memprediksi kondisi perusahaannya. Bagi peneliti berikutnya disarankan agar dapat menambah model prediksi kesulitan keuangan lain seperti Fullmer H-Score, Ohlson, dan dapat menggunakan teknik pengujian dengan uji beda untuk membandingkan hasilnya satu sama lain. Untuk objek perusahaan pembiayaan hendaknya peneliti lebih fokus pada struktur keuangan perusahaan terutama dari hal perbandingan utang dan piutang perusahaan. Karena pada dasarnya, komposisi keuangan perusahaan pembiayaan ini tidak sama dengan perusahaan lainnya. Peneliti selanjutnya dapat menambah rentang periode pengamatan lebih panjang untuk dapat menggeneralisir hasil penelitian secara keseluruhan.

\section{REFERENCES}

Adriana, A.N.2012. Analisis Prediksi Kebangkrutan Menggunakan Metode Springate Pada Perusahaan Foods and Beverages yang Terdaftar di Bursa Efek Indonesia periode 2006-2010. E-journal Repository Akuntansi Universitas Riau. 4(1) : 5-20. 
Altman,E.I. 1968. Financial Ratios, Discriminant Analysis and The Prediction of Corporate Bankruptcy. The Journal of Finance. 23[4]:589609.

Brigham, Eugene F. \& Houston, Joel F. 2012. Dasar-Dasar Manajemen Keuangan (Essentials of Financial Management). Buku Satu, Edisi Kesebelas. Jakarta: Salemba Empat.

Elrick, Helfert. A. 2003. Teknik Analisis Keuangan ; Petunjuk Praktis Untuk Mengelola dan Mengukur Kinerja Perusahaan. Edisi kedelapan. Jakarta : Erlangga.

Kasmir. 2011. Analisis Laporan Keuangan. Cetakan Keempat. Jakarta: PT. Raja Grafindo Persada.

Malau, S.,M, et.al., 2010. Prediksi Kondisi Financial Distress Debitur Sektor Perdagangan Menggunakan Binary Logit (Studi Kasus PT.Bank Sumut).

Ohlson, J.A. 1980. Financial Ratios and The Probabilistic Prediction of Bankruptcy. Journal of Accounting Research. 18(1):109-131.

Peraturan Otoritas Jasa Keuangan Nomor 10/POJK.05/2014 Pasal 4 tentang Penilaian Tingkat Resiko Perusahaan Pembiayaan.

Permana, Randy Kurnia, et,al. Prediksi Financial Distress pada Perusahaan Manufaktur di Bursa Efek Indonesia. Jurnal Bisnis dan Manajemen. 7(2) : 149 - 166.

Prihantini, N.M.E.D dan Maria M.R.S., 2013. Prediksi Kebangkrutan dengan Model Grover, Altman ZScore, Springate, dan Zmijewski pada Perusahaan Food and Beverage di Bursa Efek Indonesia. E-Journal Akuntansi Universitas Udayana. ISSN : 2302-8556

Qisthi,Dafi,et.al.2013. Analisis X-Score (Model Zmijewski) untuk Memprediksi Gejala Kebangkrutan Perusahaan (Pada Indsutri Otomotif dan Komponennya yang terdaftar di BEI Periode 2009-2011). Jurnal Administrasi Bisnis (JAB). 1(2):6877.

Swantari,A., dan Fachrul,Husein,.H. 2012. Prediksi Financial Distress Berdasarkan Kemampuan Kinerja Keuangan Pada Industri Property. MiTTra (Mice, Tour and Travel). 3(1): 1-18.

Syahfitriani. 2017. Analisis Akurasi Model Grover dan Model Ohlson dalam Memprediksi Financial Distress pada Perusahaan Pertambangan yang Terdaftar di Bursa Efek Indonesia (BEI) Periode 2010-2014. Skripsi. Universitas Maritim Raja Ali Haji.

Syahyunan, 2013. Manajemen Keuangan (Perencanaan, Analisis dan Pengendalian .Keuangan), USU Press, Medan.

Waluyo, W. 2002. Analisis Rasio-Rasio Keuangan Terhadap Prediksi Pemberian Status Kredit (Studi Empiris Kredit Komersial pada Bank "X" Cabang Bondowoso). Tesis. Universitas Diponegoro. Semarang.

Wijoyo, Nugroho Agung. 2016. Menakar Kinerja Perusahaan Pembiayaan (Kesulitan Keuangan Perusahaan Pembiayaan (Financial Distress). Jilid Kedua. Jakarta : UI-Press. 
Zakiyyah, Ufi Zuhriyatuz, et.al. 2014.

Analisis Penggunaan Model Zmijewski (X-Score) dan Altman (ZScore) untuk Memprediksi Potensi Kebangkrutan (Studi Pada Perusahaan Tekstil dan Garmen yang Terdaftar di (BEI) Bursa Efek Indonesia Periode 2009-2012. Jurnal Administrasi Bisnis (JAB). 1 